\title{
(2)
}

\section{THE STATE OF}

\section{WORLD FISHERIES AND}

AQUACULTURE

\section{2}

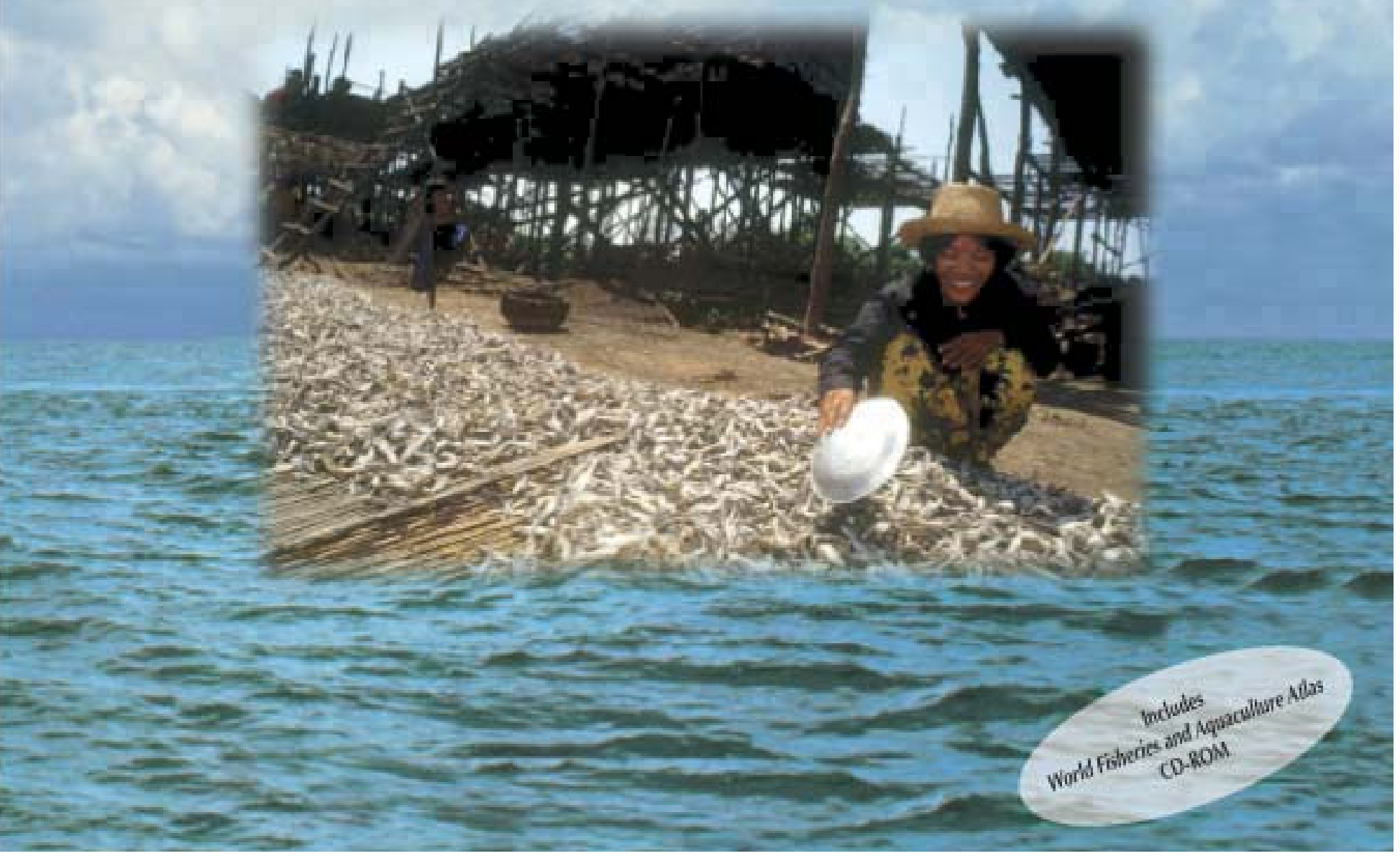


Editing, design, graphics and desktop publishing:

Editorial Group

FAO Information Division

The designations employed and the presentation of material in this information product do not imply the expression of any opinion whatsoever on the part of the Food and Agriculture Organization of the United Nations concerning the legal status of any country, territory, city or area or of its authorities, or concerning the delimitation of its frontiers or boundaries.

ISBN 92-5-104842-8

All rights reserved. Reproduction and dissemination of material in this information product for educational or other non-commercial purposes are authorized without any prior written permission from the copyright holders provided the source is fully acknowledged. Reproduction of material in this information product for resale or other commercial purposes is prohibited without written permission of the copyright holders. Applications for such permission should be addressed to the Chief, Publishing Management Service, Information Division, FAO, Viale delle Terme di Caracalla, 00100 Rome, Italy or by e-mail to copyright@fao.org

(C) FAO 2002 


\section{THE STATE OF WORLD FISHERIES AND AQUACULTURE \\ 2002}

FAO Fisheries Department 


\section{FOREWORD}

During the past two years, the international fisheries community has achieved many important developments: the International Plan of Action on Illegal, Unregulated and Unreported fishing was adopted by FAO members during the first months of 2001; in October of the same year, the Reykjavik Conference on Responsible Fisheries in the Marine Ecosystem called on the world community to promote an effective ecosystems framework for fisheries management; in November 2001, the World Trade Organization's (WTO's) Ministerial Conference in Doha paid special attention to fisheries subsidies and decided that participants in the next round of trade negotiations should aim to clarify and improve WTO disciplines on such subsidies, taking into account the importance of this sector to developing countries; at about the same time, the UN Fish Stocks Agreement came into force; and, in September 2002, the World Summit for Sustainable Development (WSSD) adopted a Plan of Implementation that is clearly focused on improving the sustainability of world fisheries. Aquaculture has received increasing attention during the past two years, as illustrated by the fact that the world's first inter-governmental body to specialize in this field, the Sub-Committee on Aquaculture of the FAO Committee on Fisheries, met in Beijing in the spring of 2002.

In many countries, these international developments have been accompanied by actions aimed at broadening and strengthening fisheries management for the purpose of achieving sustainable fisheries and aquaculture. However, results are slow to arrive, particularly in terms of rebuilding stocks or increasing fishers' incomes. This should be no surprise. Scientists have warned repeatedly that most heavily exploited stocks will take time to recover - if they can do so at all. Patience and perseverance are therefore essential, and fisheries management should foster such attitudes among all those concerned.

One of the important contributions of FAO in this regard is the biennial publication of The State of World Fisheries and Aquaculture (SOFIA), the purpose of which is to provide some of the knowledge required for understanding the fisheries sector.

As in the past, in Part 1 of SOFIA 2002 the situation in China is reported separately whenever doing otherwise might hide significant differences between developments in China and developments in the rest of the world. Part 2 highlights important issues, some of which are not new, such as the difficulty and importance of obtaining reliable fishery statistics and the plight of small-scale and artisanal fishers, while others have emerged more recently, including catch certification, antibiotics and aquaculture and an ecosystems framework for fisheries management. Part 3 contains reports on three studies that have been published recently by FAO. Part 4 reports on the findings of studies on future fish consumption and speculates about the future implications of the rising costs of capture fisheries.

It is the hope of FAO and its Fisheries Department that this new edition of SOFIA will prove to be a useful tool for facilitating a balanced and comprehensive understanding of the fisheries sector, particularly its international aspects.

Ichiro Nomura

Assistant Director-General FAO Fisheries Department 


\section{CONTENTS}

Foreword

Acknowledgements

Glossary

PART 1

WORLD REVIEW OF FISHERIES AND AQUACULTURE

Fisheries resources: trends in production, utilization and trade 3

Overview

Capture fisheries production

Fishers and fish farmers

The status of the fishing fleet

The status of fishery resources

Aquaculture

Fish utilization

26

Fish trade

29

International fisheries policy and governance

PART 2

SELECTED ISSUES FACING FISHERS AND AQUACULTURE

Implementing the ecosystem approach to capture fisheries management

Possible solutions

Recent actions

Future perspective

Reliable statistics as an essential basis for effective fisheries management

The issue

Possible solutions

Global perspective

Catch certification and catch documentation

The issue

Possible solutions

Recent actions

Future perspective

Poverty alleviation in small-scale fishing communities $\quad 69$

The issue

Possible solutions $\quad 70$

$\begin{array}{ll}\text { Recent actions } & 72\end{array}$

$\begin{array}{ll}\text { Outlook } & 73\end{array}$

$\begin{array}{ll}\text { Antibiotic residues in aquaculture products } & 74\end{array}$

$\begin{array}{ll}\text { The issue } & 74\end{array}$

$\begin{array}{ll}\text { Possible solutions } & 75\end{array}$

Recent actions $\quad 76$

$\begin{array}{lr}\text { Global perspective } & \mathbf{8 2}\end{array}$

PART 3

HIGHLIGHTS OF SPECIAL FAO STUDIES

$\begin{array}{lr}\text { Fisheries and long-term climate variability } & \mathbf{8 7}\end{array}$

$\begin{array}{lr}\text { Background } & \mathbf{8 7}\end{array}$

$\begin{array}{lr}\text { Fisheries and long-term climate fluctuations } & \mathbf{8 7}\end{array}$ 
$\begin{array}{lr}\text { Correlation between fisheries and climate } & \mathbf{8 8}\end{array}$

Forecasting possibilities $\quad 90$

Policy implications $\quad 90$

The search for an operational definition

of subsidies provided to the fisheries sector $\quad 91$

Background $\quad 91$

General considerations $\quad 92$

Subsidies $\quad 93$

Techno-economic performance of marine capture fisheries $\quad 95$

$\begin{array}{ll}\text { Introduction } & 95\end{array}$

Cost structure of small-scale fishing vessels $\quad 95$

Recent trends in financial and economic performance $\quad 97$

Aquaculture development in China: the role of public sector policies 99

$\begin{array}{lr}\text { Introduction } & 99\end{array}$

Main findings $\quad 100$

Development policies $\quad \mathbf{1 0 2}$

The way forward $\quad 105$

$\begin{array}{ll}\text { Conclusions } & 106\end{array}$

PART 4

OUTLOOK

Introduction $\quad 111$

Trends in long-term projections of fish production and consumption 111

$\begin{array}{ll}\text { Capture and aquaculture production } & 112\end{array}$

$\begin{array}{lr}\text { Consumption } & 114\end{array}$

World trade flows $\quad 117$

The long-term outlook $\quad 119$

Food and employment: the prospects $\quad 119$

$\begin{array}{ll}\text { Capture fishers } & 120\end{array}$

Aquaculturists $\quad 122$

Policy-makers $\quad 123$

$\begin{array}{ll}\text { Conclusions } & 124\end{array}$

PART 5

FISHERIES ACTIVITIES OF COUNTRY GROUPINGS

Association of Southeast Asian Nations $\quad 127$

Caribbean Community and Common Market $\quad 129$

Commonwealth of Independent States $\quad 131$

Economic Community of West African States 133

European Community $\quad 135$

Latin American Economic System $\quad 139$

League of Arab States $\quad 141$

North American Free Trade Agreement $\quad 143$

South Asian Association for Regional Cooperation $\quad 144$

Southern African Development Community $\quad 146$

South Pacific Forum $\quad 148$ 


\section{BOXES}

BOX 1

$\mathrm{FAO}^{\prime}$ s role in fishery statistics

BOX 2

China

BOX 3

Trends in high seas fisheries

BOX 4

Tracking the fishing fleets through the database of Lloyds Maritime Information Services

BOX 5

Dams, fish and fisheries:

a challenge for fishery managers and engineers

BOX 6

Aquatic biodiversity from rice-based farming systems supports rural livelihoods

BOX 7

Trade in aquaculture products

BOX 8

Illegal, unreported and unregulated fishing

BOX 9

Global estimates of income-poor small-scale fishers and related employment in marine and inland capture fisheries

BOX 10

Fisheries co-management in Aby Lagoon, Côte d'Ivoire

BOX 11

Drugs currently banned for use in raising animals in the United States (USFDA 2002)

BOX 12

Limitations inherent in long-term fish projections 


\section{TABLES}

TABLE 1

World fisheries production and utilization

TABLE 2

Fisheries production and utilization for the world excluding China

TABLE 3

Inland capture fishery production by economic class

TABLE 4

World fishers and fish farmers by continent

TABLE 5

Number of fishers (including fish farmers) in selected countries

TABLE 6

Changes to the database of Lloyds Maritime

Information Services (for fishing vessels)

TABLE 7

Flagging in and out of shipping registers (by fishing vessels)

TABLE 8

Total and per capita food fish supply by continent and economic grouping in 1999

TABLE 9

EC import bans of tuna and tuna-like species

TABLE 10

Possible purchase and user patterns

and resulting residual effects of antibiotics in aquaculture

TABLE 11

JECFA proposed MRLs relevant to aquaculture

TABLE 12

Current MRLs relevant to aquaculture in the EC EEA

TABLE 13

Current tolerances relevant to aquaculture in the United States

TABLE 14

Currently approved drugs and their MRLs in Canada

TABLE 15

Additional amended MRLs in Canada

TABLE 16

Fish consumption, net export and production trends 1997-2030 
TABLE 17

Summary of projections for 2030 based on the United States model (thousand tonnes, live weight)

TABLE 18

Estimated percentage changes in European

fish production and consumption, 1994-1998 to 2030

TABLE 19

ASEAN: fisheries and aquaculture production, food balance and trade

TABLE 20

CARICOM: fisheries and aquaculture production, food balance and trade

TABLE 21

CIS: fisheries and aquaculture production, food balance and trade

TABLE 22

ECOWAS: fisheries and aquaculture production, food balance and trade

TABLE 23

EC: fisheries and aquaculture production, food balance and trade

TABLE 24

LAES: fisheries and aquaculture production, food balance and trade

TABLE 25

League of Arab States: fisheries and aquaculture production, food balance and trade

TABLE 26

NAFTA: fisheries and aquaculture production, food balance and trade

TABLE 27

SAARC: fisheries and aquaculture production, food balance and trade

TABLE 28

SADC: fisheries and aquaculture production, food balance and trade

TABLE 29

SPF: fisheries and aquaculture production, food balance and trade 


\section{FIGURES}

FIGURE 1

World capture fisheries and aquaculture production

FIGURE 2

World fish utilization and supply, excluding China

FIGURE 3

World capture fisheries production

FIGURE 4

Marine and inland capture fisheries: top producer countries in 2000

FIGURE 5

Capture fisheries production by principal marine fishing areas in $\mathbf{2 0 0 0}$

FIGURE 6

Capture fisheries production: top species in 2000

FIGURE 7

Capture fisheries production in marine areas

FIGURE 8

Inland capture fisheries production: top ten producer countries in $\mathbf{2 0 0 0}$

FIGURE 9

China's fish utilization and supply

FIGURE 10

World catches of oceanic species (epipelagic and deep water) occurring principally in high seas areas

FIGURE 11

World trade in oceanic species

FIGURE 12

World fishers and fish farmers

FIGURE 13

Numbers of decked fishing vessels by continent

FIGURE 14

Numbers of powered vessels by continent in 1998

FIGURE 15

Numbers of decked fishing vessels in major national fleets by continent

FIGURE 16

Numbers of fishing vessels over 100 GRT recorded in

Lloyds Maritime Information Services database

FIGURE 17

Numbers of fishing vessels in the major open registers and of flag unknown 
FIGURE 18

Aquaculture production in marine and inland waters

FIGURE 19

Trend of global aquaculture production by major species groups

FIGURE 20

Global aquaculture production: proportions of species groups by environment in $\mathbf{2 0 0 0}$

FIGURE 21

Aquaculture production: major producer countries in $\mathbf{2 0 0 0}$

FIGURE 22

Aquaculture production: major species groups in $\mathbf{2 0 0 0}$

FIGURE 23

Trends in aquaculture production quantity and value

FIGURE 24

Utilization of world fisheries production (breakdown by volume)

FIGURE 25

Fish as food: per capita supply

FIGURE 26

Contribution of fish to animal protein supply

FIGURE 27

Total protein supply by continent and major food group (1997-1999 average)

FIGURE 28

Imports and exports of fishery products for different regions, indicating the net deficit or surplus

FIGURE 29

World fishery exports by major commodity groups

FIGURE 30

Net exports of selected agricultural commodities by developing countries

FIGURE 31

Trade flows by continent (percentages of total import c.i.f. values: averages for 1998-2000)

FIGURE 32

Shrimp prices (wholesale) in the United States and Japan

FIGURE 33

Skipjack tuna prices in the United States, Thailand and Africa

FIGURE 34

Groundfish prices (c\&f) in the United States 
FIGURE 35

Cephalopod prices (wholesale) in Japan

FIGURE 36

Fishmeal and soybean meal prices (c.i.f.)

in Germany and the Netherlands

FIGURE 37

Fluctuations in the main open registers

FIGURE 38

Cyclic temperature fluctuations and Japanese sardine outbursts 1600-2000

FIGURE 39

Periodicity of detrended values of global temperature anomaly (dT), negative length of day (-LOD) and zonal atmospheric circulation index $(\mathrm{ACI}) \mathbf{1 8 5 0 - 2 0 0 0}$

FIGURE 40

Dynamics of meridional (C) and zonal (WE)

forms of the atmospheric circulation index $(\mathrm{A})$ and alternation

of meridional and zonal circulation epochs (B) 1880-2040

FIGURE 41

Observed (1950-1998) and forecast (2000-2040)

catch changes for selected major commercial species in the North Atlantic and North Pacific

FIGURE 42

Sets of subsidies

FIGURE 43

Total costs of small-scale fishing vessels in Europe

FIGURE 44

Total costs of small-scale fishing vessels in Senegal

FIGURE 45

Total costs of small-scale fishing vessels in the Caribbean

FIGURE 46

Total costs of small-scale fishing vessels in Asia

FIGURE 47

World fish production and food use consumption 1976-2030

FIGURE 48

Evolution of Europe-28 total fish production over time

FIGURE 49

Japanese demand for fish to 2030 


\section{ACKNOWLEDGEMENTS}

The State of World Fisheries and Aquaculture 2002 was prepared by FAO Fisheries Department staff, led by a team comprising U. Wijkström, A. Gumy and R. Grainger. General direction was provided by the Department's management staff, including: L. Ababouch; J. Csirke; S. Garcia; J. Jia; I. Nomura; B. Satia; J. Turner; and G. Valdimarsson.

The preparation of Part 1, World review of fisheries and aquaculture, was the overall editorial responsibility of R. Grainger assisted by D. Evans (consultant), who coordinated the contributions made by L. Garibaldi (production, capture fisheries); J. Csirke (marine resources); A. Crispoldi (fishers and fishing fleets); R. Metzner (fisheries management); D. Doulman (regional fisheries governance); R. Subasinghe (aquaculture); D.M. Bartley (inland fisheries); S. Vannuccini and G. Laurenti (consumption); S.

Vannuccini (utilization and trade); and H. Josupeit (commodity trade).

Contributors to Part 2, Selected issues facing fishers and aquaculturists, included: K. Cochrane (implementing the ecosystem approach to capture fisheries management); D. Evans and R. Grainger (reliable statistics as an essential basis for fisheries management); A. Smith (catch certification and documentation); G. MacFadyean (consultant) (poverty alleviation in smallsale fishing communities); and H. Lupin, R. Subasinghe and D. Alderman (of the Centre for Environment, Fisheries and Aquaculture Science [CEFAS] UK) (antibiotic residues in aquaculture products).

Contributors to Part 3, Highlights of special FAO studies, included: J. Csirke (fisheries and long-term climate variability); the Fisheries Development Planning Service (the search for an operational definition of subsidies provided to the fisheries sector); U. Tietze (techno-economic performance of marine capture fisheries); and N. Hishamunda (aquaculture development in China: the role of public sector policies).

Part 4, Outlook, was written by C. de Young, R. Metzner and U. Wijkström.

Part 5, Fisheries activities of country groupings, was written by A. Gumy.

Several other staff members as well as non-FAO authors have contributed texts on specific issues, and they are cited in the relevant boxes throughout the publication. Information of relevance for all five parts has been provided by FAO staff in the Regional and Subregional Offices. S. Montanaro assisted with preparation of the figures and the tables.

The Editorial Group of the FAO Information Division was responsible for the editing, design and production of The State of World Fisheries and Aquaculture 2002.

Notes: Unless otherwise stated, the source of data for the figures is FAO. Data for China do not include Taiwan Province and Hong Kong and Macao Special Administrative Regions. 


\section{GLOSSARY}

ACC

Administrative Committee on

Coordination (UN)

ACP

African, Caribbean and Pacific Group of States (EC)

\section{ADI}

acceptable daily intake

AFFP

Arab Federation of Fish Producers

ASEAN

Association of Southeast Asian Nations

CAC

Codex Alimentarius Commission

\section{CARICOM}

Caribbean Community and Common Market

\section{CCAMLR}

Commission for the Conservation of Antarctic Living Resources

\section{CCP}

critical control point

\section{CCSBT}

Commission for the Conservation of Southern Bluefin Tuna

c\&f

cost and freight

c.i.f.

cost, insurance, freight

CFRAMP

CARICOM Fisheries Resource Assessment and Management Program

CFP

Common Fisheries Policy (EC)

\section{CIDA}

Canadian International Development Agency
CIS

Commonwealth of Independent States

\section{COFI}

Committee on Fisheries (FAO)

\section{CRFM}

Caribbean Regional Fisheries Mechanism (CARICOM)

\section{CWP}

Coordinating Working Party on Fishery Statistics (inter-agency)

\section{DANIDA}

Danish International Development Agency

\section{DWFN}

Distant Water Fishing Nations

EAF

ecosystem approach to fisheries

\section{EEA}

European Economic Area

EC

European Community

\section{ECOWAS}

Economic Community of West African States

EEC

European Economic Community (superseded by EC)

EEZ

exclusive economic zone

EU

European Union

\section{FFA}

South Pacific Forum Fisheries Agency (ù

\section{FIFG}

Financial Instrument for Fisheries

Guidance (EC)

\section{FISHSTAT}

Computer System for Global Fishery

Statistical Time Series 
f.o.b.

free on board

\section{GLOBEFISH}

Computerized System of Fish Marketing Information

GRT

gross registered ton

\section{HACCP}

Hazard Analysis and Critical Control Point (system)

HIPC

heavily-indebted poor countries

IACSD

Inter-agency Committee on Sustainable Development

\section{IATTC}

Inter-American Tropical Tuna Commission

\section{IBSFC}

International Baltic Sea Fishery

Commission

\section{ICCAT}

International Commission for the

Conservation of Atlantic Tunas

\section{ICES}

International Council for the Exploration of the Sea

\section{ICFA}

International Coalition of Fisheries

Associations

\section{ICLARM}

International Centre for Living Aquatic

Resources Management

\section{IMF}

International Monetary Fund

IMO

International Maritime Organization

IOC

Intergovernmental Oceanographic

Commission

IOTC

Indian Ocean Tuna Commission
IPOA-IUU

International Plan of Action to Prevent, Deter and Eliminate Illegal, Unreported and Unregulated Fishing

IUU

illegal, unreported and unregulated (fishing)

\section{JECFA}

Joint FAO/WHO Expert Committee on Food Additives

\section{LAES}

Latin American Economic System

\section{LIFDC}

low-income food-deficit country

MCS

monitoring, control and surveillance

MRL

maximum residue limit

\section{MRLVD}

maximum limit for residues of veterinary drugs (CAC)

\section{NACA}

Network of Aquaculture Centres in Asia-Pacific

\section{NAFTA}

North American Free Trade Agreement

\section{NGO}

non-governmental organization

NRC

National Research Council (United States)

\section{OECD}

Organisation for Economic Co-operation and Development

\section{OIE}

International Office of Epizootics

\section{OLDEPESCA}

Latin American Organization for Fisheries Development

PRSPs

Poverty Reduction Strategy Papers 
$x v i$ RFB

regional fishery body

RFMO

regional fisheries management organization

\section{SAARC}

South Asian Association for Regional Cooperation

\section{SADC}

Southern African Development

Community

SEAFDEC

Southeast Asian Fisheries Development Centre

\section{SEAFO}

Southeast Atlantic Fisheries Organization

\section{SFLP}

Sustainable Fisheries Livelihoods

Programme

SPF

South Pacific Forum

SPS

Sanitary and Phytosanitary Agreement (WTO)

TAC

total allowable catch

\section{UNCED}

United Nations Conference on

Environment and Development

\section{UNCLOS}

United Nations Conference on the Law of the Sea

\section{UNEP}

United Nations Environment Programme

\section{USFDA}

United Stated Food and Drug

Administration

\section{VMS}

Vessel Monitoring System

\section{WECAFC}

Western Central Atlantic Fisheries

Commission

\section{WHO}

World Health Organization

WSSD

World Summit for Sustainable Development

WTO

World Trade Organization

Note: The data on food fish supply (total and per capita) presented for the world in the O verview section of Part 1 (Tables 1 and 2) differ from those presented in the Fish utilization section of Part 1 (Table 8) owing to different time frames. The source of the more detailed figures reported in the latter is the FAO Fisheries Circular N o. 821, Rev. 6. [Laurenti, G. (comp.) 1961-1999. Fish and fishery products: world apparent consumption statistics based on food balance sheets], which was compiled using statistics held in the FAO fishery statistical database in August 2001. The world total data presented in the O verview (Tables 1 and 2) are based on more recent production figures of $\mathrm{M}$ arch 2002, which also incorporated historical revisions. The food fish supply data in Tables 1 and 2 are indicative and may be subject to further revision when the food balance sheets are updated. 